\title{
Synthesis of Polystyrene Sulfonate and Its Characterization as a Polymer Electrolite Membrane
}

\author{
Emil Salim ${ }^{1 *}$, Afrizal $^{1}$, Zilfadli $^{1}$ \\ ${ }^{1}$ Chemistry Department, Faculty of Matematics and Natural Sciences, Andalas University, Padang \\ *correspondence email: emilsalim@sci.unand.ac.id
}

\begin{abstract}
This study aims to synthesize polystyrene sulfonate (PSS) from polystyrene (PS) isolated from waste styrofoam. Sulfonation reaction of polystyrene was conducted using acetyl sulfonate as sulfonating agents with variation times and temperatures. The sulfonated products were characterized using FT-IR spectrophotometer, degree of sulfonation, cation exchange capacity, water uptake and thermal stability. The FTIR spectrums show vibration of $\mathrm{O}-\mathrm{H}$ streching at wave number $3300-3400 \mathrm{~cm}^{-1}, S=O$ streching at the wave number $1050-1200 \mathrm{~cm}$ ${ }^{1}$ which indicates the presence of sulfonate groups. Sulfonation reaction at $40^{\circ} \mathrm{C}$ for 2 hours (SPS-40-2) gives the highest degree of sulfonation, cation exchange capacity, water uptake with values $1,960 \%, 0.1880 \mathrm{meq} / \mathrm{gr}, 9.04 \%$ respectively. Thermal gravimetry analysis shows that polystyrene sulfonate has better thermal stability than polystyrene.
\end{abstract}

Keywords: Polistyrene, styrofoam, acetyl sulfonate, polystyrene sulfonate

\section{INTRODUCTION}

Polystyrene is a synthetic polymer used as the main ingredient in the manufacture of styrofoam. Styrofoam is widely used as a protective electronic device from impact or as a practical food packaging. The use of styrofoam is very beneficial for food sellers and electronic equipment sellers because styrofoam is not easy to leak, practical, lightweight, and economical. The increasing use of styrofoam creates new problems for the environment. Styrofoam waste is difficult to degrade by microorganisms in the soil (Wahytuningsih, 2007) (Pramono et al., 2012). To reduce the problems that arise, the polystyrene can be isolated from styrofoam and modified into new polymer for any application, such as electrolyte polymer membrane, coagulant, adsorbant, etc.

The polymer electrolyte membrane can be applied in fuel cells. The most widely used fuel cell is the polymer 
Salim, E. Akta Kimia Indonesia Vol. 6(2), 2021, 153-161

electrolyte membrane fuel cells (PEMFC)

This type of fuel cell can be operated at temperatures of $60^{\circ} \mathrm{C}-150^{\circ} \mathrm{C}$. The fuction of the membrane in the PEMFC system is to deliver protons $\left(\mathrm{H}^{+}\right.$ions) from the anode to the cathode. In the process of $\mathrm{H}^{+}$ formation from $\mathrm{H}_{2}$ the fuel cell requires heating. The higher the temperature, the more perfect the breakdown of $\mathrm{H}_{2}$ molecules will be (Pramono et al., 2012).

The polystyrene structure can be modified into polystyrene sulfonate with the sulfonation reaction. The reaction is an aromatic electrophilic substitution reaction using a sulfonating agent in which one of the hydrogen atoms in the benzene ring is replaced by a sulfonic acid group $\left(-\mathrm{SO}_{3} \mathrm{H}\right)$. During the reaction, the polymer and the sulfonation agent must be homogeneous, so the maximum reaction occurs. The solvent used must not react with the polymer or with the sulfonating agent (Haryono et al., 2003). The degree of sulfonation of polystyrene greatly affects the properties of the sulfonated polymer obtained. The addition of sulfonate groups to polystyrene can reduce the crystallinity properties which affect its thermal properties, hydrophilic strength, and proton conductivity depending on the degree of sulfonation (Pramono et al., 2012 (Wicaksono, 2012).

\section{METHODOLOGY}

DOI: http://dx.doi.org/10.12962/j25493736.v6i2.1091
Preparation of polystyrene

Polystyrene was isolated from waste styrofoam by dissolving styrofoam in toluene. Polystyrene was precipitated using ethanol. The precipitate was dried with oven at $60^{\circ} \mathrm{C}$ for 24 hours. The isolated polystyrene was kept at room temperature for next experiments.

\section{Preparation of sulfonating agent}

A total of $10 \mathrm{~mL}$ of dichloromethane and $3 \mathrm{~mL}$ of acetic anhydride are mixed in a three-necked round flask under inert conditions using $\mathrm{N}_{2}$ gas. The solution was cooled at $0^{\circ} \mathrm{C}$, then $2 \mathrm{~mL}$ of $98 \%(\mathrm{v} / \mathrm{v})$ $\mathrm{H}_{2} \mathrm{SO}_{4}$ was added. The mixture was stirred until homogeneous. The acetyl sulfonate obtained is immediately used for sulfonation reaction (Al-sabagh et al., 2017).

\section{Synthesis of polystyrene sulfonate}

A total of 10 grams of isolated polystyrene was dissolved in $100 \mathrm{~mL}$ dichloromethane in a three-necked round flask. The mixture was stirred until homogeneous and flowed with $\mathrm{N}_{2}$ gas for 25 minutes, acetyl sulfate solution was added. The sulfonation process was carried out at $23^{\circ} \mathrm{C}, 40^{\circ} \mathrm{C}$, and $60^{\circ} \mathrm{C}$ for 2 hours, 4 hours, and 6 hours. To stop the sulfonation process, $10 \mathrm{~mL}$ of 2-propanol solution was added to form a sulfonated polystyrene precipitate. The precipitate was washed with distilled water, then separated by decantation. The sulfonated polystyrene 
Salim, E. Akta Kimia Indonesia Vol. 6(2), 2021, 153-161

precipitate obtained was dried in oven at $60^{\circ} \mathrm{C}$ for 24 hours, after the products were weighed and characterized using FTIR spectrophotometer (Al-sabagh et al., 2017).

\section{Determination of degree of sulfonation} and cation exchange capacity

A total of 1 gram of sulfonated polystyrene was weighed and immersed in a vial bottle with $10 \mathrm{~mL} 0.1 \mathrm{M} \mathrm{NaCl}$ solution for 48 hours. The sample is separated and the solution is put into a 25 $\mathrm{mL}$ erlenmeyer. Two drops of phenolphthalein was added and titrated with $0.02 \mathrm{M} \mathrm{NaOH}$ (Yee et al., 2013). The degree of sulfonation (DS) and cation exchange capacity (CEC) were calculated using equations:

$\mathrm{DS}=\frac{\mathrm{M} \times \mathrm{V} \times \mathrm{df}}{\text { mass of sample } \times \frac{1000 \mathrm{mg}}{M W \text { of styrene }}} \times 100 \%$

Where:

$$
\mathrm{CEC}=\frac{\mathrm{M} \times \mathrm{V}}{\text { mass of sample }}
$$

$M:$ Concentration of $\mathrm{NaOH}(\mathrm{mmol} / \mathrm{mL})$

$V \quad:$ Volume of $\mathrm{NaOH}(\mathrm{mL})$

df : Dilution factor

$9.62: 1 \mathrm{~g}$ of polystyrene sulfonate $100 \%$

\section{Water uptake}

Samples were cut into small pieces and determined the initial weight (Wo). The samples were put in petri dish containing distilled water for 24 hours. The soaked sample is then removed and dried using tissue paper, the final weight of the sample (W) is weighed to obtain the DOI: http://dx.doi.org/10.12962/j25493736.v6i2.1091 percentage of water absorbed (Fahnur, 2017).

$$
\text { Water uptake }=\% \frac{\mathrm{W}-\mathrm{Wo}}{\mathrm{Wo}} \times 100
$$

\section{Thermogravimetric analysis}

Samples of polystyrene and polystyrene sulfonates $(1 \mathrm{mg})$ were put into the container, then placed in the testing chamber with a heating program from $30^{\circ} \mathrm{C}$ to $600^{\circ} \mathrm{C}$ using an alumina container with a temperature rise rate of $20^{\circ} \mathrm{C}$ and nitrogen gas flow rate of $20 \mathrm{~mL} /$ minute. Thermograms were recorded to see the degradation temperature of the sample and the weight of the sample after degradation (Rawi et al., 2018).

\section{RESULT AND DISCUSSION}

\section{Isolation of Polystyrene}

Polystyrene isolation is carried out to obtain polystyrene from styrofoam. The results of polystyrene isolation with 80 grams of styrofoam using toluene and redeposition using ethanol were obtained as much as 72.08 grams with a percentage of polystyrene in styrofoam is about $90 \%$. Styrofoam consists of $90-95 \%$ polystyrene and $5-10 \%$ n-butane gas (Wahyuningsih, 2007).

\section{Synthesis of polystyrene sulfonate}

Synthesis of polystyrene sulfonate was carried out through sulfonation reaction. This reaction is used to substitute one of the hydrogen atoms in polystyrene 
Salim, E. Akta Kimia Indonesia Vol. 6(2), 2021, 153-161

benzene with the sulfonate group in acetyl sulfonate (Haryono et al., 2003). The synthesis reaction process is carried out with several variations in temperature and time to see the optimum conditions. The percent yields of sulfonation reaction are shown in Table 1.

In Table 1, the sample SPS-40-2 gives the highest percent yield. Temperature affects the percentage of the yield. The sulfonation reaction takes place at temperatures ranging from $20^{\circ} \mathrm{C}$ to $80^{\circ} \mathrm{C}$, when the reaction temperature is too low the rate of the sulfonation reaction runs slowly because the kinetic energy decreases and makes the particles move slower, while at too high temperature will form intermolecular and intramolecular cross-links (Kyozo, 1986).

\section{FTIR analysis}

Sample characterization by FTIR spectophotometry was carried out to detect the molecular structure of the compound by identifying the functional groups of the compound. In this characterrization, it was carried out to determine the sulfonate functional groups of sulfonated polystyrene. The FT-IR spectrums from PS and PSS are shown in Figure 1.

Table 1. Percent yield of polystyrene sulfonate

\begin{tabular}{ccc}
\hline No & Sample variation & \% yield \\
\hline 1 & PSS-23-2 & 83,671 \\
2 & PSS-40-2 & 94,655 \\
3 & PSS-40-4 & 92,564 \\
4 & PSS-40-6 & 91,065 \\
5 & PSS-60-2 & 72,416 \\
\multicolumn{3}{c}{ Where: } \\
& PSS-23-2 & : Polystyrene sulfonate $23^{\circ} \mathrm{C} 2$ hours \\
& PSS-40-2 & : Polystyrene sulfonate $40^{\circ} \mathrm{C}$ 2 hours \\
& PSS-40-4 & : Polystyrene sulfonate $40^{\circ} \mathrm{C} 4$ hours \\
& PSS-40-6 & : Polystyrene sulfonate $40^{\circ} \mathrm{C} 6$ hours \\
& PSS-60-2 & : Polystyrene sulfonate $60^{\circ} \mathrm{C} 2$ hours
\end{tabular}

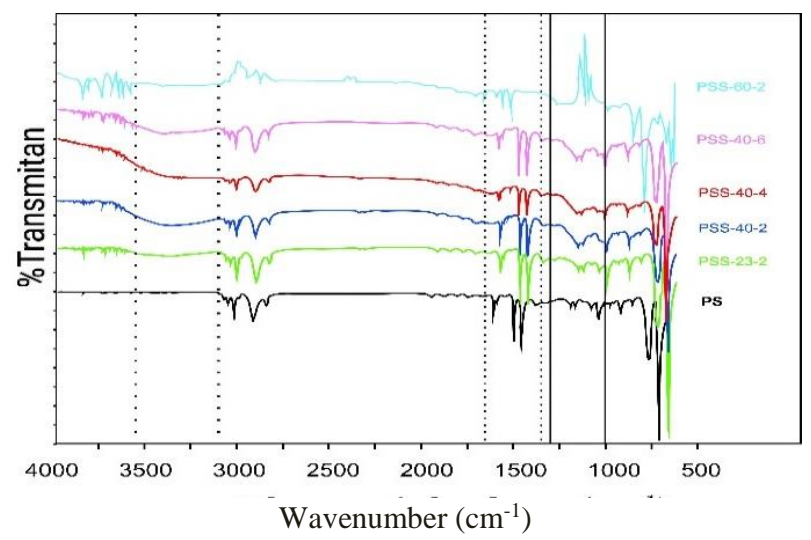

Figure 1. Spectrum FTIR of PS and PSS 
Salim, E. Akta Kimia Indonesia Vol. 6(2), 2021, 153-161

Figure 1 shows the spectrum of FTIR of PS and SPS. From the the spectrum above, there is a stretching vibration of $\mathrm{C}$ $\mathrm{H}$ of alkanes at wave numbers 2800-3000 $\mathrm{cm}^{-1}$, and $\mathrm{C}-\mathrm{H}$ aromatic absorption at wave numbers $3000-3100 \mathrm{~cm}^{-1}$, bond vibrations of $\mathrm{C}=\mathrm{C}$ and $\mathrm{C}-\mathrm{C}$ of the benzene ring at wave numbers $1500-1675 \mathrm{~cm}^{-1}$.

In the FTIR spectrum analysis of samples PSS-23-2, PSS-40-2, PSS-40-4, PSS-40-6 above, it can be interfered that the sulfonation process was successful. As evidence, $\mathrm{O}-\mathrm{H}$ groups absorption of the sulfonate groups were observed at wave numbers $3300-3400 \mathrm{~cm}^{-1}$, then there is also a vibration of $\mathrm{O}=\mathrm{S}=\mathrm{O}$ bonds of the sulfonate group at wave numbers 1050$1200 \mathrm{~cm}^{-1}$ (Rubinger \& Paoli, 2007) (Martins et al., 2003) (Fariqi, 2014). Whereas the PSS-60-2 synthesis was not successful because there was no expected absorption in the spectrum. Therefore, the results of the PSS-60-2 synthesis could not be used for further tests.

\section{Degree of sulfonation (DS) and Cation Exchange Capacity (CEC)}

The degree of sulfonation was carried out to see the amount of sulfonate contained in polystyrene. The degree of sulfonation was carried out by the acidbase titration method. The results of the degree of sulfonation is shown in Table 2.

Table 2 shows that the temperature affects the sulfonation reaction. Reaction at temperature of $23^{\circ} \mathrm{C}$ obtained a relatively smaller degree of sulfonation compared to the reaction temperature of $40^{\circ} \mathrm{C}$. This is because the sulfonation reaction rate is slow without heating. The heating process serves to accelerate the interaction process between particles.

In Table 2, it also can be observed that the time affects the sulfonation reaction. The variations of time were carried out at a reaction temperature of $40^{\circ} \mathrm{C}$. The value of the degree of sulfonation gets smaller with the longer the reaction time. This happens because the sulfonate group attached to polystyrene (PS) is partially broken down, this process is also called the desulfonation process which is caused by the reaction with water (Fariqi, 2014).

The cation exchange capacity (CEC) was carried out to determine the ability of PSS to replace cations bound to its functional groups with cations of other compounds, testing was also carried out in conjunction by determining the degree of sulfonation using the acid-base titration method. The value of the cation exchange capacity is shown in Table 3. 
Salim, E. Akta Kimia Indonesia Vol. 6(2), 2021, 153-161

Table 2. DS values of PSS

\begin{tabular}{ccc}
\hline No & Sample variation & DS (\%) \\
\hline 1 & PSS-23-2 & 1,167 \\
2 & PSS-40-2 & 1,960 \\
3 & PSS-40-4 & 1,522 \\
4 & PSS-40-6 & 1,141 \\
\hline
\end{tabular}

Table 3. Cation Exchange Capacity (CEC) of PS and PSS

\begin{tabular}{ccc}
\hline No & Sample varriation & CEC $(\mathrm{meq} / \mathrm{g})$ \\
\hline 1 & PSS-23-2 & 0,1120 \\
2 & PSS-40-2 & 0,1880 \\
3 & PSS-40-4 & 0,1460 \\
4 & PSS-40-6 & 0,1097 \\
\hline
\end{tabular}

In Table 3, we can see that temperature and time affect the CEC value. SPS-40-2 gives the highes cation exchange capacity. This is directly related to the degree of sulfonation (DS). Sulfonate content is influenced by reaction temperature, reaction time, pressure, and volume of sulfonating agents (Fariqi, 2014).

\section{Water Uptake}

The water uptake test was carried out to determine the ability of the sample to bind water molecules. It was determined by the percentage increase in the final weight of the sample after immersion and water absorption. The results of the water uptake test is shown in Table 4.

In Table 4, sample PSS-40-2 gives the highest water uptake value with a percentage of $9.04 \%$. This value is directly related to the degree of sulfonation where sulfonate groups are polar. The sulfonate groups in sulfonated polystyrene make the polymer more hydrophilic. This property allows sulfonate groups to interact with water molecules (Martins et al., 2003).

Table 4. Water Uptake of PS and SPS

\begin{tabular}{ccc}
\hline No & Sampel variation & Water Uptake $(\%)$ \\
\hline 1 & PS & 4,57 \\
2 & PSS-23-2 & 1,8 \\
2 & PSS-40-2 & 9,04 \\
3 & PSS-40-4 & 6,8 \\
4 & PSS-40-6 & 7,29 \\
\hline
\end{tabular}


Salim, E. Akta Kimia Indonesia Vol. 6(2), 2021, 153-161

\section{Thermogravimetric analysis}

Thermogravimetric analysis (TGA) was carried out to determine the resistance or thermal stability of the polymer and the effect of the sulfonate groups on the polymer chain. Thermal stability is used to determine the temperature range of the sample so it can be applied at a certain temperature without experiencing degradation in heating. Figure 2 shows the thermogram of PS and SPS.

The degradation temperature ranges in PS and PSS affect the stability of thermal resistance. The longer the temperature range, the more stable the thermal resistance of the sample (Manikandam et al., 2001). Thermal stability of PS and PSS can be seen in Table 5.
In Table 5, the data describe the thermal stability of PS and PSS with temperature and time. From the data, it can be analyzed that polystyrene sulfonate undergoes $5 \%$ degradation first compared to polystyrene, but at $320^{\circ} \mathrm{C}$, polystyrene undergoes $10 \%$ degradation to polystyrene sulfonate which takes longer to degrade at $10 \%$. This is due to the effect of the addition of sulfonate groups on polystyrene. Based on these data, PS has a degradation temperature range of 200$320^{\circ} \mathrm{C}$, and PSS has a degradation temperature range of around $170-400^{\circ} \mathrm{C}$ which indicates that PSS has better thermal stability than PS (Manikandam et al., 2001).

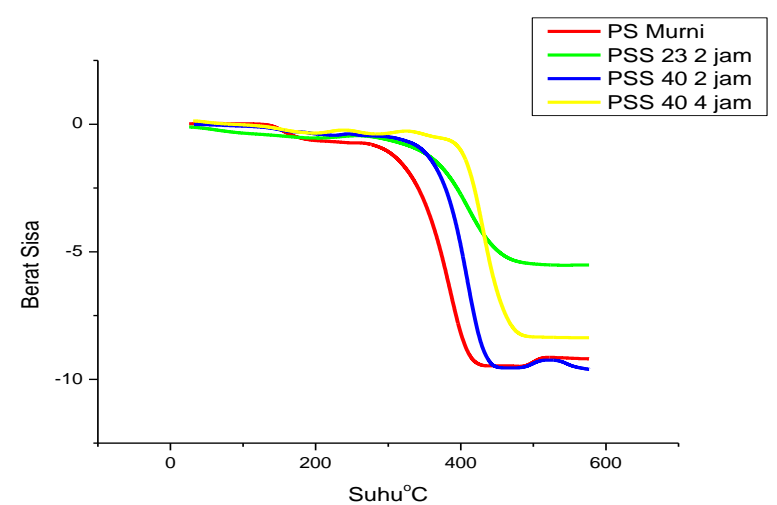

Figure 2. Termogram of PS and PSS

Table 5. Thermal stability of PS and PSS at 5\% and 10\% degradation of the sample

\begin{tabular}{|c|c|c|c|}
\hline Sample & $\begin{array}{c}\mathrm{T}\left({ }^{\circ} \mathrm{C}\right) \\
5 \%\end{array}$ & $\begin{array}{c}\mathrm{T}\left({ }^{\circ} \mathrm{C}\right) \\
10 \%\end{array}$ & $\begin{array}{c}\text { Residual } \\
\text { weight (\%wt) }\end{array}$ \\
\hline PS & 200 & 320 & 10,07 \\
\hline PSS-23-2 & 170 & 340 & 49,77 \\
\hline PSS-40-2 & 180 & 360 & 9,33 \\
\hline PSS-40-4 & 175 & 370 & 22,06 \\
\hline
\end{tabular}




\section{CONCLUSION}

The research showed that polystyrene can be modified into polystyrene sulfonate. Degree of sulfonation is influenced by the temperature and reaction time. The highest degree of sulfonation, cation exchange capacity and water uptake were obtained at $40^{\circ} \mathrm{C}$ for 2 hours. The characterization by thermogravimetry PSS showed that sulfonated polystyrene gives better thermal stability compared to polystyrene.

\section{REFERENCES}

[1] Wahyuningsih, T. 2007. Pembuatan Polistirena Sulfonat dari Limbah Polistirena sebagai Koagulan dalam Pengolahan Air. Skripsi, Jurusan Kimia Universitas Jember, Jember.

[2] Pramono, E., Wicaksono, A., Priyadi, \& Wulansari, J. 2012. Pengaruh Derajat Sulfonasi terhadap Degradasi Termal Polistirena Tersulfonasi. Indonesian journal of applied physics, 2(2), 157-163. https://eprints.uns.ac.id/1721/1/11-edipramoono_edit1.pdf

[3] Haryono, A., Astrini, N., \& Wuyaningsih, S.R. 2003. Sintesis Polistiren Sulfonat sebagai Koagulan Polimer, Prosiding Simposium Nasional Polimer IV, 61-66. https://digilib.batan.go.id/ppin/katalog/ DOI: http://dx.doi.org/10.12962/j25493736.v6i2.1091 file/1410-8720-2003-1-061.pdf

[4] Wicaksono, A. 2012. Sintesis dan Karakterisasi Membran Komposit Polistirena Tersulfonasi dengan Zeolit untuk Aplikasi Membran Polimer Elektrolit. Skripsi, Universitas Sebelas Maret. Perpustakaan.uns.ac.id.

[5] Al-sabagh, A.M, Moustafa, Y.M., Hamdy, A., Killa, H.M., Ghanem, R.T.M. \& Morsi, R.E. 2017. Preparation and Characterization of Sulfonated Polystyrene/magnetite Nanocomposites for Organic Dye Adsorption. Journal of Petroleum, 27, 403-413. https://doi.org/10.1016/j.ejpe.2017.07.0 $\underline{04}$

[6] Yee, R., Zhang, S.L., Kaisong, \& Ladewig, B.P. 2013. The Effect of Sulfonated Poly(ether ether ketone) Ion Exchange Preparation Conditions on Membrane Properties. Journal Membrane, 3(3), 182-195. https://www.ncbi.nlm.nih.gov/pmc/articl es/PMC4021939/

[7] Fahnur, M. 2017. Pembuatan Uji Ketahanan dan Struktur Mikro Plastik Biodegradable dengan Variasi Kitosan dan Konsentrasi Pati Biji Nangka. Skripsi, Jurusan Fisika Fakultas Sains and Teknologi: UIN Alauddin Makassar. http://repositori.uinalauddin.ac.id/7518/1/MARDIANA\%20 FAHNUR\%20SKRIPSI.pdf 
Salim, E. Akta Kimia Indonesia Vol. 6(2), 2021, 153-161

[8] Rawi, F.M., \& Jaapar, K.H. 2018.

Polystyrene, Journal Braz. Chem. Soc.,

Characterization of Polystyrene with

14 ,

797-802.

TGA/DSC and FESEM/EDX. Faculty

https://doi.org/10.1590/S0103-

of Engineering: University of

$\underline{50532003000500015}$

Nottingham.

https://www.researchgate.net/publicati

on/332072221

[12] Fariqi. M.H. 2014. Studi Waktu

Reaksi Sulfonasi Polistiren terhadap

Konduktivitas Proton dan Kekuatan

[9] Kyozo, K., Mikuchi, F., Terao, T. 1986. Sulfonation Method of Polystyrene. United states Patent, 4(671), 903.

[10] Rubinger, \& Paoli, M. 2007.

Sulfonated Polystyrene Polymer

Humidity Sensor: Syntehsis and

Characterization. Sensors and

actuators B: Chemical, 123(1), 42-49.

https://doi:10.1016/j.snb.2006.07.019

[11] Martins, C. R., Ruggeri, G., \& Paoli, M. 2003. Synthesis in Pilot Plant Scale and Physical Properties of Sulfonated

Tarik Polistiren untuk Membran pada

Sel Bahan Bakar Polymer Electrolyte

Membrane Fuel Cell (PEMFC), Tesis,

Fakultas Teknologi Industri Institut

Teknologi Sepuluh November (ITS).

Surabaya.

[13] Manikandam, N.K.C., Thomas, S., \& Grroenickx, G. 2001. Thermal and Dynamic Mechanical Analysis of Polystyrene Composites Reiforced with Short Sisal Fibres. Journal Composites Sciences and Technology, 61, 25192529. https://doi: 10.12691/ajmse-2-4-1 